\title{
The Efficacy of Syllabi of General English Courses at Undergraduate Level in Bangladesh: An Evaluation
}

\author{
Amina Rashid \\ English Language Institute, Jazan University, Jazan, Kingdom of Saudi Arabia \\ Md. Masud Rana \\ English Language Institute, Jazan University, Jazan, Kingdom of Saudi Arabia
}

\begin{abstract}
A good syllabus contributes to achieving better learning outcomes. Academic institutions often invest huge amounts in preparing the so-called 'panacea' of a syllabus hoping they could meet the demand of the highly competitive world. Now, however, educationists often get divided on what is instrumental to gaining a higher level of learning outcomes: Is it the quality of syllabus, or the kind of teaching approaches, or quality of teachers and learners, or good academic environment with a proper support system or a combination of all the above? While the academic process around the globe continues amidst these unresolved questions, teaching and learning English in Bangladeshi tertiary institutions for undergraduate students is no exception. Although almost all the students at undergraduate level take some sort of English language course like general English Language (GEL), or foundation English (FE) course, they fail to function when it comes to using the language in a real-life situation. This paper strives to trace out why the students cannot communicate in English properly even after 10 plus years of exposure to the language - 1/2 years at the tertiary level and 8 to 10 years at the primary and secondary levels. The research has adopted both quantitative and qualitative research methods and used two different questionnaires to collect data for the study. Delving into a thorough analysis of the existing syllabuses, the study contends that the syllabus cannot quite prepare the students to be able to function in English in a real-world scenario and, therefore, recommends a revamping of the syllabuses is necessary to produce pragmatic and pedagogical efficacy.
\end{abstract}

Index Terms - syllabi, English Language Teaching (ELT), General English Language (GEL) courses, Communicative Language Teaching (CLT), Grammar Translation Method (GTM)

\section{INTRODUCTION}

\section{A. Background of the Study}

English, considered as the lingua franca of the modern world, has become the pathway of global communication and global access to knowledge. All branches of human knowledge are now available in English. It is an important promoter of socio-economic advancement and is highly required for those seeking higher opportunities in all spheres of life. In Bangladesh, as per the constitution, English is still a foreign language (The Constitution of the People's Republic of Bangladesh, 2021). Nevertheless, the actual usage of English at all levels across the country implies more than that. People use English in their everyday life to cope with the outer world, achieve higher education, and obviously, to attain national progress and prosperity. Communicative competence and proficiency in English at the global stage as well as in the context of Bangladesh have been working as an indicator of success (Rahman et.al, 2019; Farooqui, 2014; Hamid, 2010). Therefore, communicative competence especially in all four skills i.e. reading, writing, listening, and speaking with a high premium on speaking should be the focal point of GEL courses at undergraduate level in Bangladesh. Besides, at undergraduate level, students are not empty vessels rather they have sufficient prior grammatical knowledge acquired from their secondary and higher secondary levels of education (Sultana, 2021). Therefore, English should be taught in perspective of promoting and consolidating communication skills to enhance student communicative competence. The syllabus should state clearly the aims and objectives of teaching English at undergraduate level. Therefore, a critical evaluation of the syllabuses of GEL courses is highly required and this study aims to figure out the strengths and shortcomings in light of pragmatic and pedagogic effectiveness.

B. Objective of the Study

The objective of this study is to assess the strengths and relative drawbacks of existing syllabuses of GEL courses at undergraduate level in Bangladesh.

C. Rationale of the Study 
A complete and organized syllabus is the overall plan for the learning process, a description or specification of content to be covered and evaluated through examination (Stern, 1984; Yalden 1984), an important source of information and reassurance for teachers as well as learners, especially, in situations where the target language is not used predominantly outside the classroom. A syllabus is the framework of teaching-learning activities that should fulfill all sorts of practical needs (Widdoson, 1978). Language Teaching Syllabus (LTS) addresses the aims and objectives of ELT. Therefore, the ELT teachers and learners should have a clear understanding of their practicing syllabuses.

At undergraduate level in Bangladesh, the existing syllabuses help students become linguistically competent and ignore functional activities and eventually students acquire the rules of linguistic usage, but cannot use the language fluently and communicatively in a real-life situation (Wali 2018). A thorough study in this regard is therefore required and hence this research will scrutinize how realistic, pragmatic, and pedagogical the prevailing syllabuses are to manifest the goal of ELT at Undergraduate level. In addition, this study might be a reliable source of information for educationists to peer into the GEL syllabuses at undergraduate level for the improvement of ELT in Bangladesh.

\section{Hypothesis of the Study}

The current GEL syllabuses are purely grammatical, which primarily focus on learning the rules of grammar, vocabulary and developing reading and writing skills. It helps the students become linguistically competent but cannot help them master the actual manifestation of that knowledge. Therefore, the undergraduate students fail to acquire communicative competence to cope up in the present context.

\section{E. Limitations of the Study}

This study is a critical evaluation of GEL syllabuses at undergraduate level in Bangladesh. Critical evaluation requires data from a different perspective. However, the study has collected data through questionnaires and written comments from teachers and students. It could have been comprehensive if we had collected more information through interviews, class observation, etc. At present, there are 45 public and 103 private universities in Bangladesh (UGC 2021) and this study has selected only one university. Due to time constraints, we could not include and examine all the syllabuses across the country.

\section{LITERATURE REVIEW}

To evaluate syllabi of general English courses at undergraduate level in Bangladesh, it is necessary to review past researches related to the current study to carry out this research more comprehensively. To date, no researchers have conducted in-depth research on GEL or FE courses of undergraduate students in Bangladesh though we have found out numerous foreign researchers have conducted research relating to EFL syllabuses in their context. Therefore, this area demands an in-depth study to improve English language teaching at undergraduate level in Bangladesh.

Sultana et.al (2019) in evaluating the fundamental English language courses at public engineering universities in Bangladesh find the existing syllabus is more structural than functional. Therefore, students cannot communicate properly due to their lack of adequate practices of language during the courses. Alongside other recommendations, they also suggest that students need to be competent in all 4-skill to accomplish communication purposes.

According to Rahman \& Jelane 2021, the current English courses at tertiary level in Bangladesh could not help students attain communicative competence especially in speaking as it neglects the notional and functional aspects of language learning and teaching. Speaking and listening skills have got less importance whereas instructors spend most of the time in teaching grammar, reading, and writing. Therefore, GEL courses could not reach to satisfactory level at tertiary level in Bangladesh (Khan, 2010; Sudha, 2017). The current GEL syllabuses at undergraduate level do not focus on 4-skill with equal importance and listening-speaking are neglected to a greater extend. Students are good at reading \& writing but lack presentation skills as well as interpersonal skills (Wali 2018, Mamun 2015).

Gautam (1988) gives an account of a survey that he conducted at the college level in Haryana state, India and the primary aim of his study was to make a critical assessment of the principal trends and features of English teaching program at the college level. He found the pedagogical implications of the new changes (teaching the skills of communication) had yet to be examined in detail and the outcome of this critical examination had to be formulated in terms of certain guidelines to the teacher regarding his classroom methods of instruction.

Teaching and learning a language is more effective when students involve themselves in interaction especially in a socio-cultural context and when learning content solves practical issues in everyday life. Social interactions such as how to start and close a conversation, turn-taking, accepting and declining invitation require communicative competence more than linguistic competence contradicts Chomsky's theory of linguistics competence (Chomsky, 1965). That is why, the use of language in context is essential and learners should know the appropriate use of language in a certain situation (Larsen-Freeman 2004, Wilkins 1976, Hymes 1971).

Brown (1994) focuses on CLT and finds several countries across the world prioritize learning and teaching English for communicative purposes rather than academic activities or passing a test only due to its global demand in the current situation. The goal of CLT is to establish a convenient route for worldwide communication.

Nagaraj (1996) gives a detailed description of ELT methods with a target to educate teachers of ELT. He suggests that from the light of this information teachers have to make the final choice about what they do and how they want to 
do it. He only says that the insight that has shaped the recent trends in language teaching - that 'being structurally correct' is only a part of what is involved in language ability. Therefore, emphasis has gone on CLT that recognizes the teaching of 'communicative competence.

O'Neill (2000) notes that communicative language teaching has enormous intuitive appeal. Language means interaction, to exchange views to each other meaningfully. The main target of learning a language is to perform communication. He emphasizes accuracy as a vital part of fluency and therefore assumes grammar plays a pivotal role in CLT. He also observes many teachers and learners could not understand grammar effectively especially its morphology and syntax that govern language as per the structural syllabus. However, morphology and syntax are only two components of grammar. On the other hand, CLT has emphasized the role of semantics in language learning. As CLT focuses on making meaning in the language, the learner's goal of language learning in the communicative classroom is to acquire the grammar and to understand them to transform them into meaning.

As a teacher working with international groups, Belchamber (2008) gives an overview of CLT and shows them ways to prepare course materials to make lessons more communicative or interactive. CLT suggests preparing lessons to be student-centered but it does not mean they are ungrammatical. The instructors play a very important role in the process of setting up activities so that communication takes place.

In her article, Thuleen (1996) states some drawbacks of GTM that it spends little time on oral practice. Besides, the rigidity and the type of error correction that this method suggests can hamper student's learning processes. Despite having all these negative traits, GTM possesses some positive aspects also. She suggests the GT method can be tempered with other approaches to create a more flexible and conductive methodology (02). Indeed, GTM is appropriate for primary and high school levels where students require knowing the basics about the target language. However, at e tertiary level, they need the practical use of that language, that is, "communicative competence".

Marks (2008) learned two foreign languages at school through GTM and acquired linguistics competence but at the time of speaking in different socio-linguistics contexts he could not transform his knowledge to speak fluently and faced that there were lots of essential everyday words and expressions that he simply did not know. Marks speaks for GTM at the elementary level where ELT teachers formulate the foundation of the fellows. However, at tertiary level, they need not repeat that knowledge; rather they should motivate students to the practical use of that knowledge.

Richards and Rodgers (1986) mention GTM emphasizes mastering reading and writing and " ignores speaking or listening skills (3)". It focuses on grammar rules, vocabulary, and translation. However, structural competence is important for learning a language but it is not inclusive, does not cover all aspects of teaching and learning processes. Having mastery of linguistic competence does not necessarily mean that one may formulate that knowledge into meaningful communication (Richards 2006, Altun, 2015).". " Communicative competence consists of two components: the first part is linguistics competence, and the knowledge of grammar rules and their meaning. The second element is knowledge of the functions language is used for (Larsen-Freeman, 2004)". Learners do not need all the grammatical rules for communication and over-emphasis on mastering rules neglects the basic function of language (Wilkins 1979:82 as cited in Abdallah 2001)

Teaching and learning the English language especially 4-skill in some Arab universities are still bound in the academic institution only (Abdalla (2001). The contemporary English language teachers hold the notion that the effective way is to learn a language by using that language instead of memorizing forms in isolation. A language learner's performance depends more on performance than linguistic competence. The grammatical syllabus is formbased and demands accurate use of rules rather than performance. The actual use of language is more important than knowledge of linguistic competence (Willy 1990). Japanese students have developed a tendency to interact, communicate with others in English without imposing a heavy burden of memorizing rules of grammar. They want to be fluent in speaking, want to communicate more naturally in different language contexts rather than focusing on grammar. (Rabbini 2002)

The ability to communicate is the goal of foreign language learning that cannot be achieved only by mastering structures (grammar and vocabulary). Learners also need functional aspects of language to cope with the everyday situation and CLT incorporates both structural and functional aspects of language to enable communication successfully (Littlewood, 1981).

\section{RESEARCH Methodology}

The study has followed both the qualitative and quantitative approaches. This is qualitative in the sense that it has collected the personal comments of the strengths and weaknesses of the syllabuses from the undergraduate English language teachers and the students of Bangladesh. It has also reviewed literature, made various analyses, drawn a final recommendation and conclusion. It is a quantitative analysis because it has calculated the percentage of data provided by the respondents. Two separate questionnaires were prepared for collecting primary data.

\section{A. Study Area}

For the study, the existing syllabuses of several disciplines of Khulna University have been selected. As this is a pilot project, the study has selected syllabuses of five disciplines and they are almost of the same category.

\section{B. Sample Design}


Simple random sampling has been applied for this study. According to Dornyei (2010), "samples are supposed to be the representative participants that are selected from a larger community or population" (as cited in Sultana et al 2019). In this study, 50 samples have been selected randomly. Of the 50 respondents, 10 were English language teachers from the English discipline, and 40 students participated from different disciplines. Among the 10 faculties, 57\% were lecturers, 35\% were Assistant professors and the rest of the $8 \%$ were associate professors and professors, and age ranged from 28 to 55 . The students who participated in this study were from the first year to 2nd year of Bachelor's degrees in different disciplines.

\section{Data Collection}

As the primary data is the main source of information for this study, the data collection method is chosen to collect accurate information. For the quantitative study, two separate questionnaires were used to collect data from both the teachers and students. For the qualitative study, the authors requested participating teachers and students to provide their opinions in writing.

\section{Data Processing and Analysis}

The study has revised the collected data and information meticulously using the following two steps: (I) Data compilation: The collected data has been grouped, categorized, and finally compiled systematically according to the objectives. (II) Data Editing: Data has been edited to ensure that all type of information has been collected from the field survey and to eliminate the possible errors and omissions. Finally, the data has been presented through figures followed by a short analysis.

\section{RESEARCH FINDINGS}

\section{A. Analysis and Evaluation of Teacher's Data}

1. The Nature and Scope of Current GEL Syllabuses:

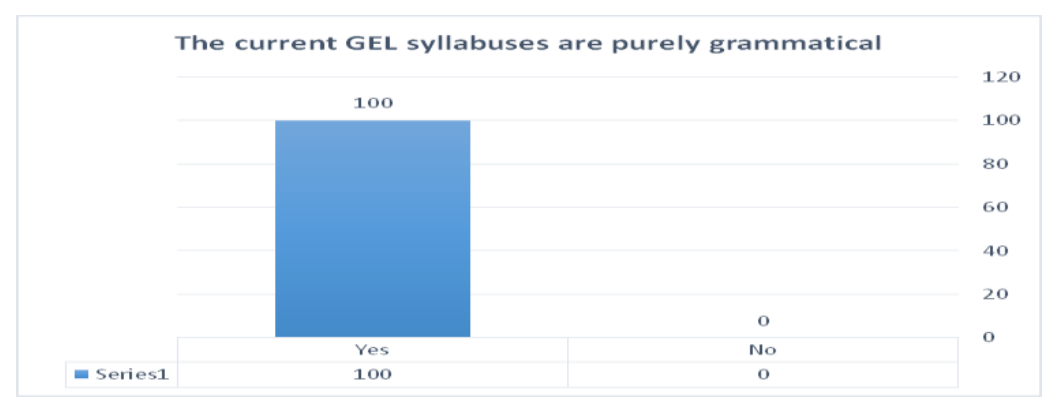

Figure 1. The current GEL syllabuses are grammatical

Figure 1 shows all the participant teachers agree with the opinion that the existing GEL syllabuses of undergraduate students in Bangladesh enhance student's grammatical knowledge and develop their reading and writing skills. Therefore, the syllabuses are purely grammatical.

2. The Status of CLT in the Existing GEL Syllabuses:

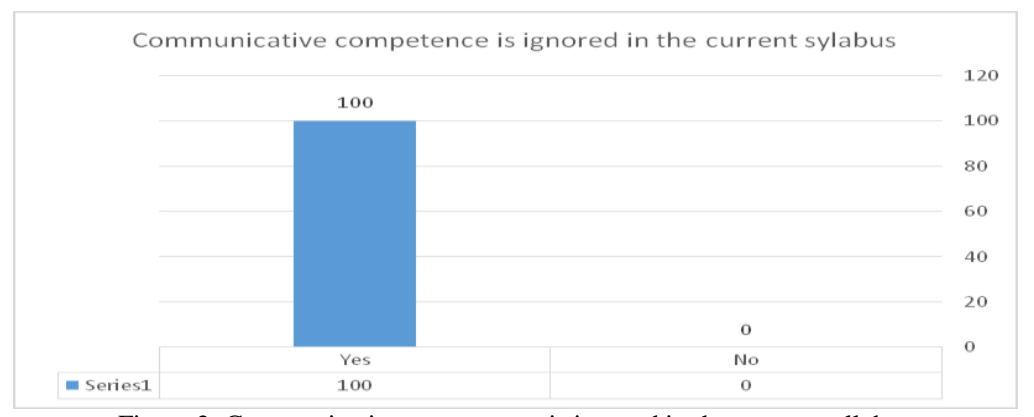

Figure 2. Communicative competence is ignored in the current syllabus

The results show $100 \%$ of respondents (figure 2) agree that the current undergraduate syllabuses are mainly grammatical and teaching and learning of English for communicative purposes is ignored.

3. The Demand of Communicative Syllabuses in the Present Context: 


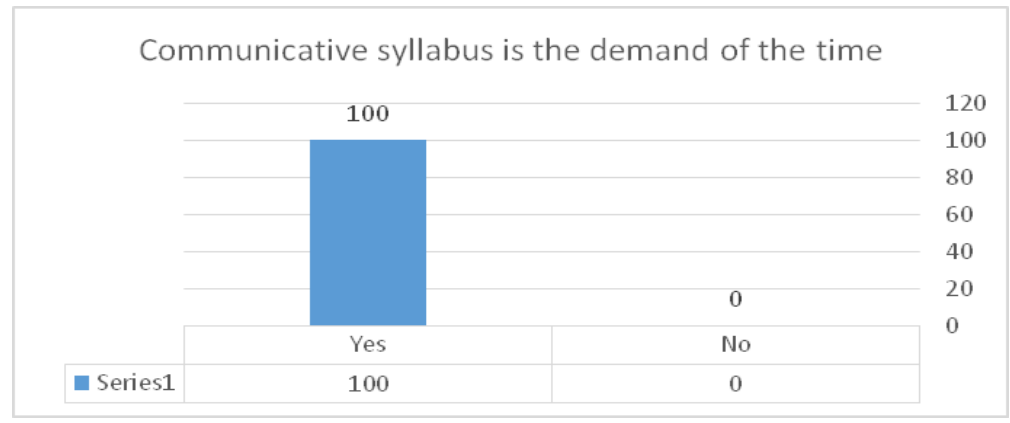

Figure 3. The demand of communicative competence

Again, everyone who participated (figure 3) strongly suggests that communicative syllabus which covers all the "four dimensions- grammatical competence, sociolinguistic competence, discourse competence and strategic competence (Canale, 1983)" should be the guiding principle for general English courses of undergraduate level in Bangladesh.

4. Shortcomings of Present English Language Testing System:

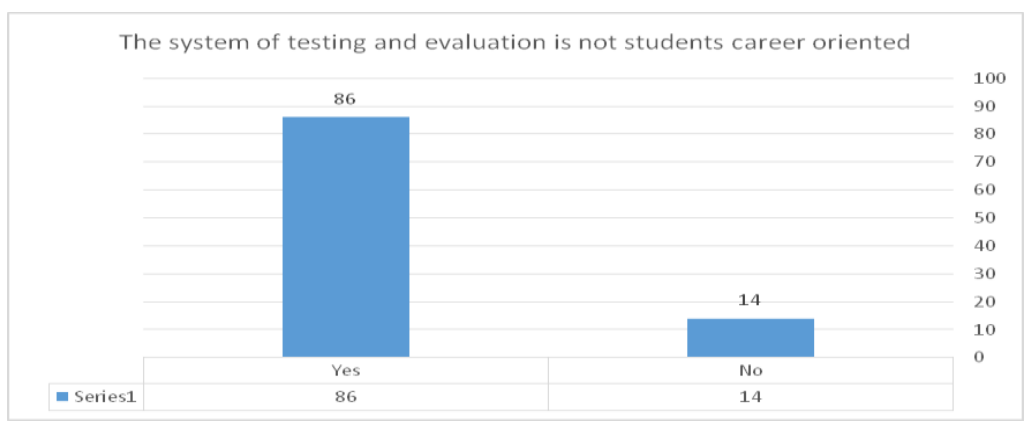

Figure 4. The system of testing and evaluation is not student career oriented

Figure 4 shows $86 \%$ of teachers think the existing testing and evaluation system needs to be modified. The traditional testing system does not emphasize oral communication and mostly ignores listening and speaking.

\section{B. Analysis and Evaluation of Student's Data}

Scope of student-questionnaire:

- $\quad$ Students' interest in learning English, their needs, and requirements.

- $\quad$ Their attitude to learning English at the Undergraduate level.

- Their assessment of the existing syllabuses.

- Their evaluation of their classroom activities.

- $\quad$ Their attitude toward the present testing system.

- Their suggestions to make the GEL Courses more purposeful and career-oriented.

1. Student's Interest and Disinterest in Learning English:

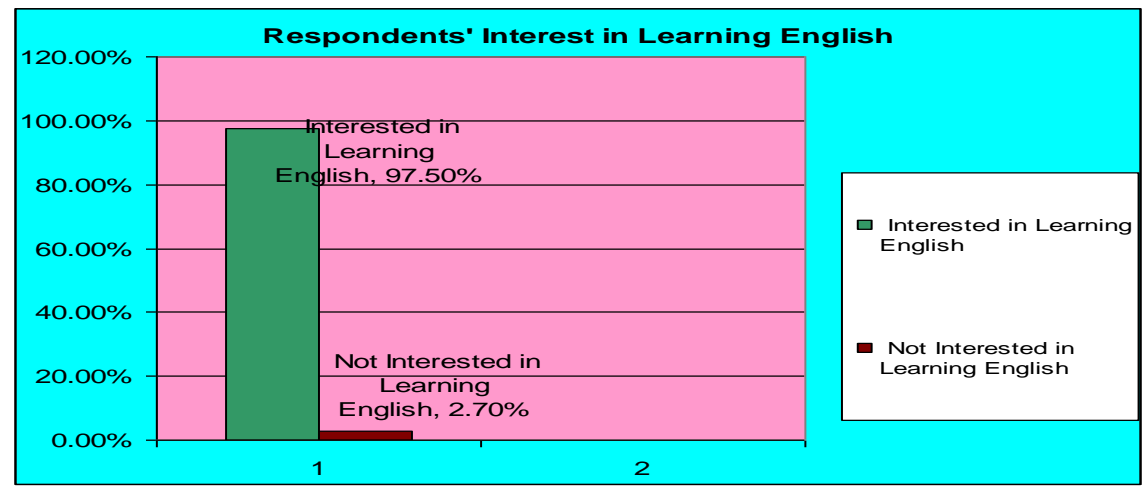

Figure 5. Student's interest and disinterest in learning English

Figure 5 indicates that $97.5 \%$ of respondents are interested in learning English, even though English is their optional course in the syllabus whereas only $2.5 \%$ are disinterested.

2. Speaking is the Most Neglected Part in the Existing Syllabuses: 


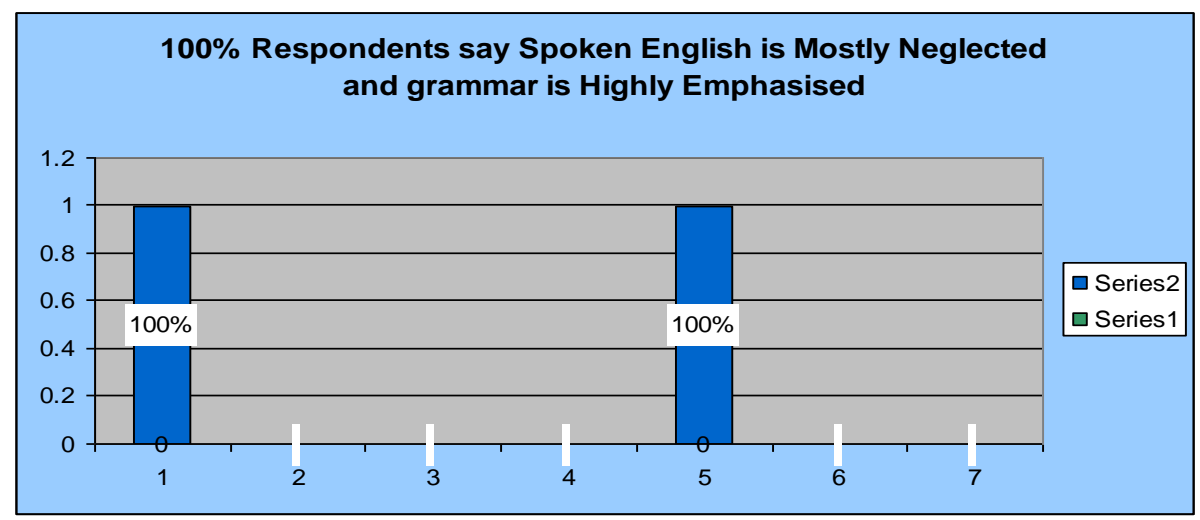

Figure 6. The most neglected part in the syllabuses is spoken English

Figure 6 shows $100 \%$ of respondents agree that grammar gets the supreme importance in the courses and spoken English is the most neglected skill. As a result, their knowledge of grammar develops, but their fluency in speaking remains poor.

3. The Position and Function of Listening Skill in the Syllabuses:

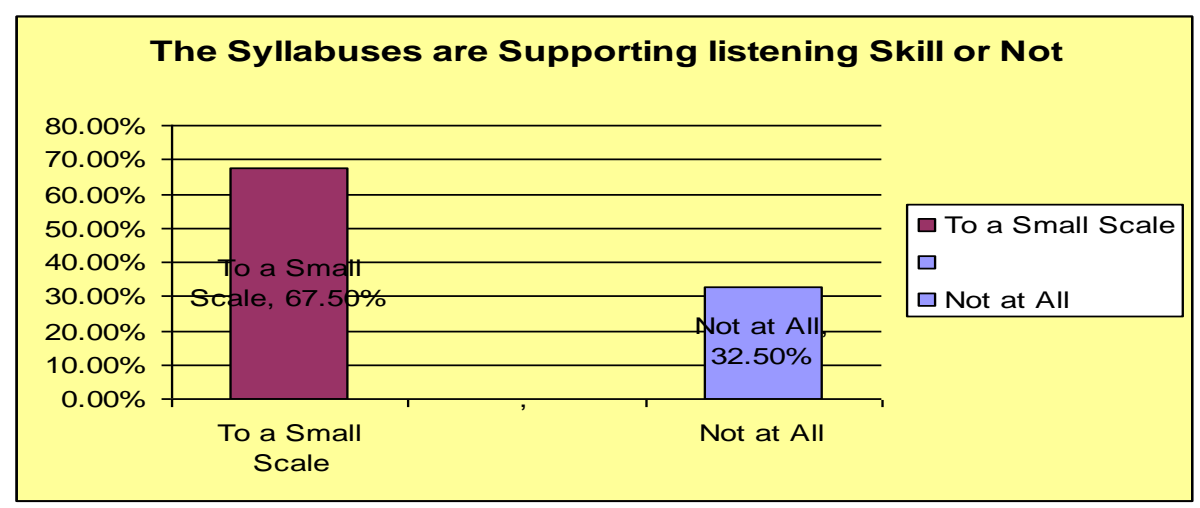

Figure 7. The position and function of listening skill in the syllabuses

Figure 7 shows that $67.5 \%$ of respondents think they receive the very least supports from their existing syllabuses to develop their listening skills and that is not sufficient. Moreover, 32.5\% of students believe that their syllabuses do not prompt them to develop their listening skills at all.

\section{Student's Role in the Classroom:}

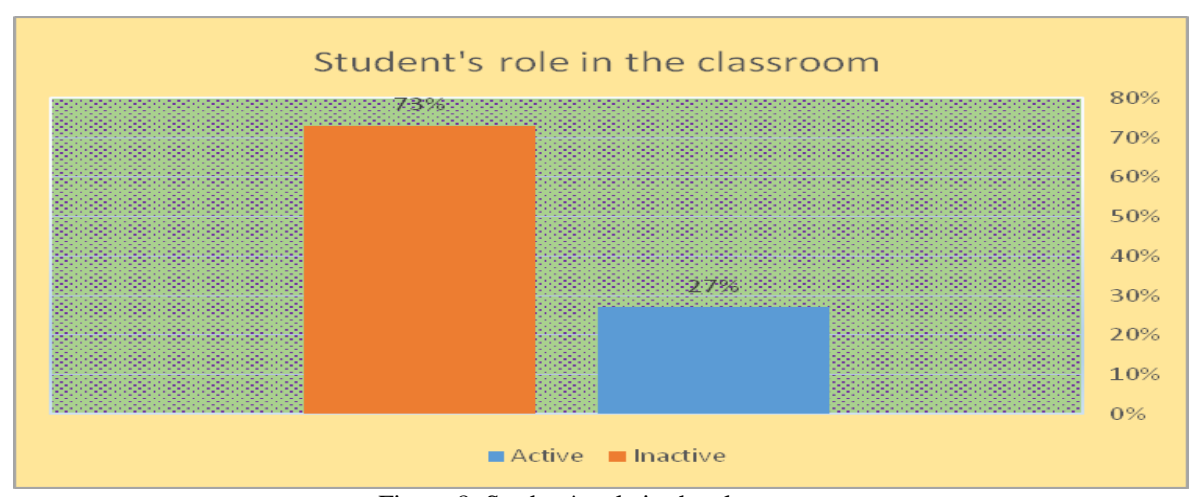

Figure 8. Student's role in the classroom

Figure 8 indicates that $73 \%$ of students remain passive in the classroom. They only listen to the instructors whereas the instructor follows the traditional lecture mode and dominates the whole class. Only $27 \%$ of respondents assume that they sometimes respond and ask a question to the teacher.

\section{Effectiveness of the Present Syllabuses:}




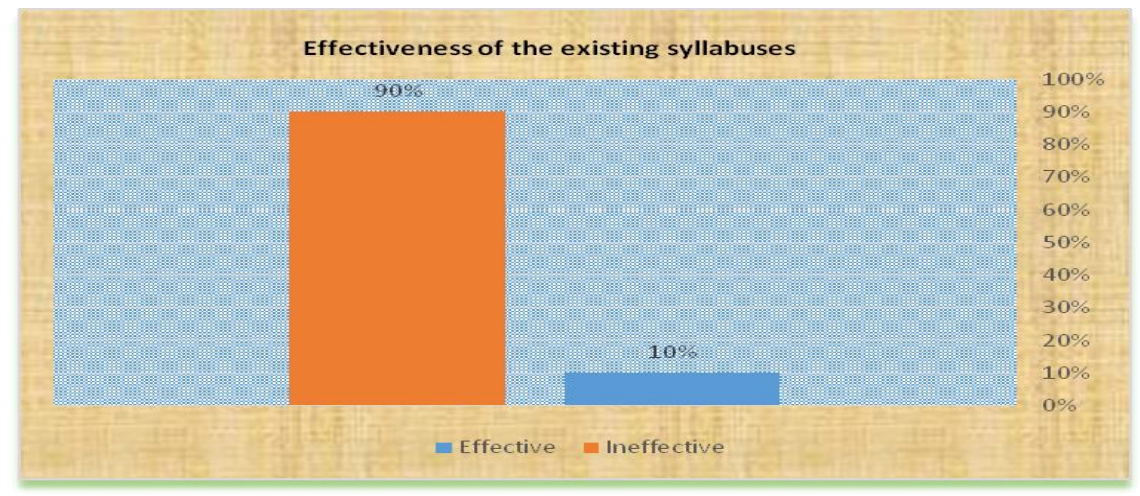

Figure 9. Effectiveness of the present syllabuses

According to Figure 9, 90\% of respondents acknowledge that they have a lacking in successful communication. They have acquired linguistics competence, can read, and write more or less correctly but they have difficulties mainly in their speaking. They cannot speak fluently in social context appropriately; they are hesitant while communicating with others.

\section{Communicative Competence should be the Goal for Learning English in the Present Context:}

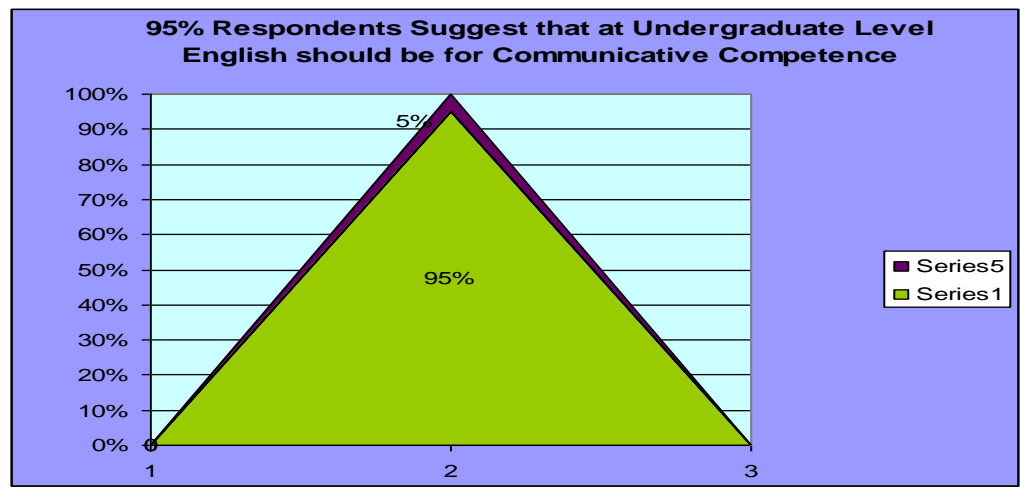

Figure 10. Communicative competence should be the goal for learning English

Figure 10 clarifies that $95 \%$ of respondents suggest that at the undergraduate level, English should be learned to enhance their communicative competence. They hold the notion they have enough grammatical knowledge from their S.S.C and H.S.C level of education. Therefore, at the undergraduate level, as they have prior grammatical knowledge, they should emphasize on communicative competence.

\section{Student's Evaluation of Present Syllabuses:}

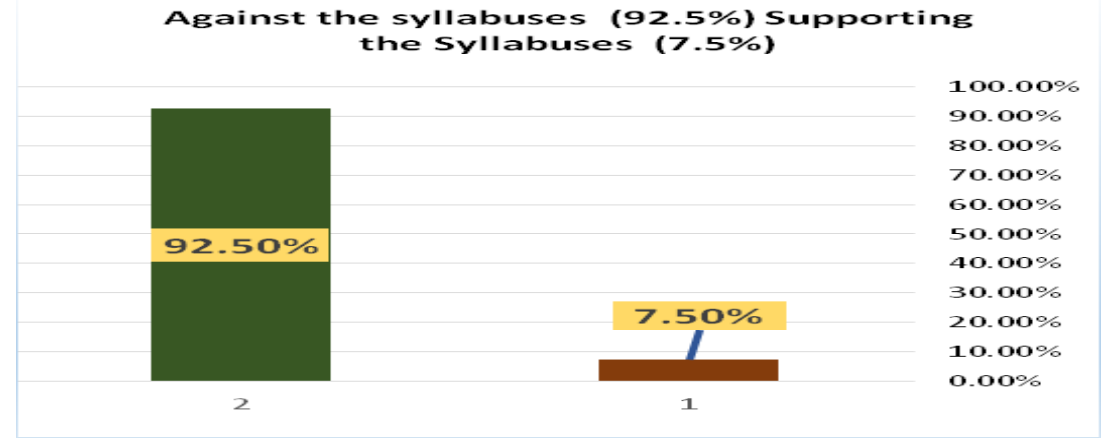

Figure 11. Student's evaluation of present syllabuses

Figure 11 clarifies that $92.5 \%$ of students are against the existing syllabuses. They think that their syllabuses need to be designed based on CLT. Only $7.5 \%$ of respondents assume the existing grammatical syllabuses are doing good to meet their needs.

\section{Existing Testing System should be Modified:}




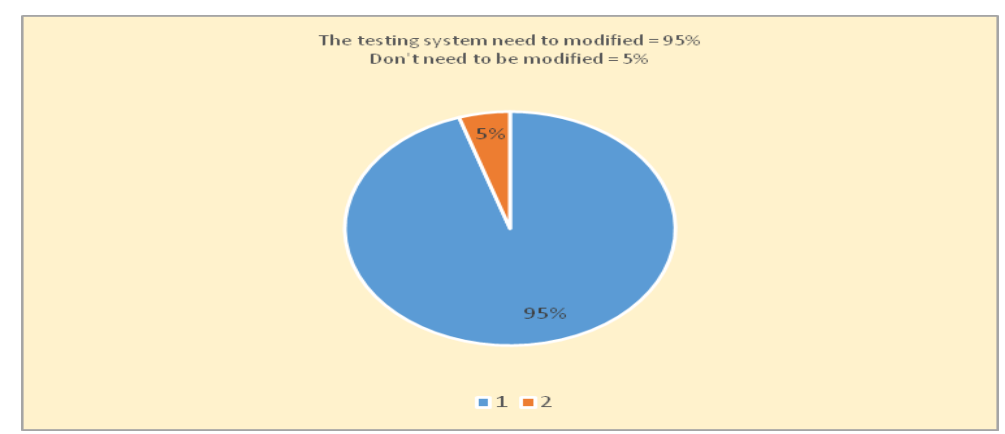

Figure 12. Existing Testing System should be modified

Figure 12 shows that $95 \%$ of respondents think the preset testing and evaluation system cannot help them reach their goal and therefore need to be modified. The current testing system improves their writing skill, but cannot improve their fluency in speaking. They assume that instead of emphasizing on written tests more attention can be paid to active performance, group work, pair work, class presentation, viva-voce, etc. to attain communicative competence.

\section{Discussion}

The study has provided a great chance to peer into the GEL syllabuses of undergraduate students, their strengths, and shortcomings. The study finds that the current GEL syllabuses of undergraduate level are grammar-based, teachercentered, and mostly based on written tests, which is shown in the following diagram.

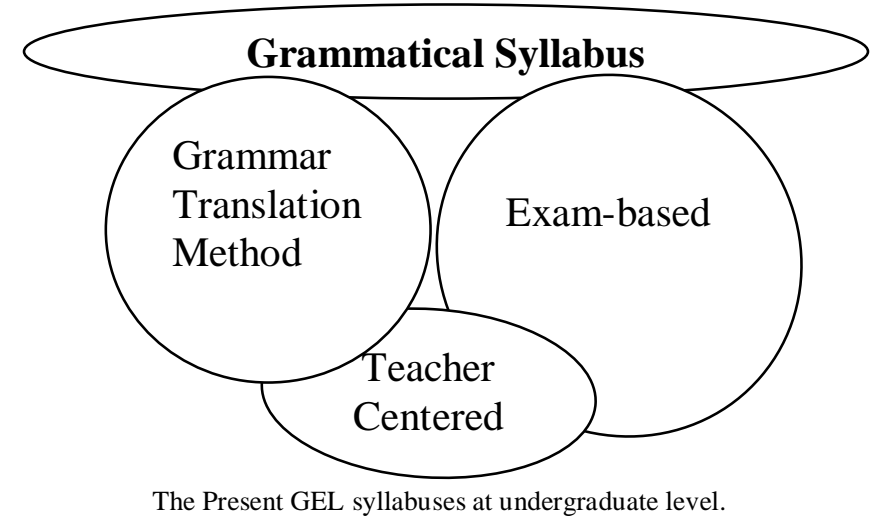

All the teachers who participate in the study consider the existing GEL syllabuses of undergraduate students are purely grammatical, and learning English for communicative purposes is ignored. Finally, they strongly support and recommend communicative competence as the dire need of undergraduate students in the global context and it should be the prime goal at the undergraduate level. Most of the teachers $(85.72 \%)$ think the current syllabus and its testing system cannot fulfill the student's needs required for professional life. All the participants strongly suggest communicative syllabus, which covers all the four dimensions: "grammatical competence, sociolinguistic competence, discourse competence, and strategic competence" (Canale, 1983), should be the guiding principle for GEL courses at $\mathrm{t}$ undergraduate level in Bangladesh.

On the other hand, $92.5 \%$ of students respond against the existing syllabuses. In the current syllabuses only grammatical aspects, reading and writing comprehensions get the focus whereas speaking and listening are the most neglected skills. They suggest at the undergraduate level students have enough prior grammatical knowledge acquired from their secondary and higher secondary levels. Therefore, at this level students are more enthusiastic to master a high level of accuracy and fluency, i.e. "communicative competence". At the same time, $90 \%$ of respondents point out that at the undergraduate level students have a lacking of successful communication and the main difficulty lies in their speaking. They cannot speak fluently; they hesitate and are nervous and shy while speaking with others. $67.5 \%$ respondents assume their existing syllabus allow them for listening comprehension to a small scale which is not sufficient for developing listening skill successfully. Again, 95\% of respondents recommend GEL courses for more than one term in their four-year graduation course to improve ELT. All the participants think the existing testing system needs to be changed and instead written tests, active performance, presentation; role-play, pair-work, group-work, etc. can get priority.

\section{A. Strengths of the Existing Undergraduate GEL Syllabuses}


The data collected from teachers and students (both quantitative and qualitative data) finds the current GEL syllabuses of undergraduate students are purely grammatical. Alongside its limitations, it has also some positive aspects including:

- The grammatical syllabus improves student's grammatical efficiency and the knowledge of grammar is considered as the base of any language.

- The syllabus highly focuses on writing comprehensions such as official correspondence, report writing, précis and paragraph writing, dialogue and letter writing, etc. Therefore, students can improve reading and writing skills whereas they face difficulty in listening and speaking.

- The syllabus trains the students to be the master of parts of speech, phrases and clauses, tense and voice, affixes, synonyms, and antonyms, etc. Hence the students' knowledge of grammar rules and vocabulary develops.

\section{B. Drawbacks of the Undergraduate GEL Syllabuses}

- Despite having some positive features, the existing syllabuses have failed to reach the goal and expectations of undergraduate students in Bangladesh. For example:

- The syllabuses do not allow students for classroom activities required to acquire a reasonable degree of communicative competence for various purposes outside the classroom.

- Little attention is paid to enhancing speaking and listening skills in the syllabuses although both the teachers and students have emphasized it.

- The students learn the rules of grammar rather than the fluency of expression in English. The syllabus does not pay equal attention to all four skills.

- The current syllabus does not provide any chance for drill in the aural-oral skills.

- The syllabus stresses knowing the rules and vocabulary but ignores the actual manifestation of that competence i.e. form is more important than meaning.

- It views language as a system of grammatical and vocabulary items and offers language samples excluding their social and cultural contexts. Thus, the communicative aspect of the language is neglected.

\section{RECOMMENDATIONS}

As per the findings of the field study and the existing language teaching and learning theories, methodologies, and syllabuses, the following recommendations can be taken into consideration to prompt ELT at the undergraduate level in Bangladesh.

Syllabuses are the overall plan for the learning process and it is a cardinal factor for the success or failure of English language courses at undergraduate level. To prompt and to produce pragmatic and pedagogical effectiveness of English language teaching at undergraduate level of Bangladesh, the study proposes the following recommendations: Communicative syllabus, which is based on communicative language teaching method, can be designed for GEL courses.

- To develop communicative efficiency in English emphasis should be given on free handwriting, conversation, presentation, group work, pair work, role-play, etc.

- The classroom teaching should be reciprocal where students will play an active role.

- The traditional lecture mood system should be replaced by CLT theories and practices.

- The GEL courses should be prescribed more than one term/ semester in four years graduation courses.

- The present testing system also needs to be developed. Instead of testing linguistic competence i.e. writing a paragraph, essay, letter, or comprehension, priority should be given for class presentation or public speaking.

- Alongside other skill tests, speaking and listening should be evaluated and tested.

- To achieve a higher level of proficiency in English, students have to take responsibility for their learning and at the same time, the teachers should be sincere, professional, and committed to intended the goal in the syllabi.

- The majority of the instructors and students who participated in this study agree that despite having some positive aspects, the existing structural syllabuses fall short of the student's expectations because of multifaceted problems. The current syllabuses are grammatical, the focus is naturally on the forms, and all grammar rules are taught throughout the courses. Nevertheless, language is not mastered when all grammatical forms have been learned. The focus on forms only serves to divorce learning from meaning and context. Actually, alongside grammar rules, other aspects of language learning are required to use the language successfully for meaningful communication. Linguistics competence is one of the parts of the communicative syllabus along with other aspects of meanings and functions. Therefore, it is inclusive and covers all aspects and activities required to acquire communicative competence. The basic assumption of this syllabus is that learning is facilitated by activities, which include real communication. This syllabus aims at teaching communication through language i.e. language as communication, rather than language for communication. It enables students to use the language actively outside the classroom. It is a learner-centered, semantic base syllabus, which focuses on doing something through language. It emphasizes on effectiveness, fluency, and 
appropriateness in learner performance over formal accuracy. Therefore, a communicative syllabus can be a very authentic, pragmatic, and dynamic syllabus for the undergraduate students of Bangladesh.

\section{CONCLUSION}

A grammatical/structural syllabus is a product-oriented, content-based syllabus, which emphasizes on knowledge of language structures that learners can acquire through formal instructions. It assumes that the form and the meaning of language have one-to-one relation, ignores the functional aspect of meaning, and focuses only on one aspect of language, i.e., formal grammar. It hardly helps learners enhance communicative ability in the language. On the contrary, a communicative syllabus is based on the communicative language teaching (CLT) method that emphasizes communication or interaction as the means and the ultimate goal of learning a foreign language. It covers all the dimensions of language learning and engages the learners to use language for meaningful purposes in an everyday situation. In the contemporary global world, English language proficiency is just not a fashion; rather it is a requirement and tool of communication around the world. It is a top-ranking language by population and is known as a bridge language, common language, or trade language. For the economic growth and devolvement of Bangladesh as a whole, English undoubtedly plays a vital role and, therefore, an appropriate syllabus for GEL courses at undergraduate level in Bangladesh is a crying need in the present-day perspective.

\section{REFERENCES}

[1] Abdala, A. Y. (2001). The significance of incorporating language skills into EFL syllabus. Academia. https://www.academia.edu/9190121(accessed 20/07/2021).

[2] Altun, M. (2015). The evolvement of the term 'Communicative Competence'. International Journal of Social Sciences \& Educational Studies, 2, (1):16-19. www.tiu.edu.iq

[3] Belchamber, R. (2007). The advantages of communicative language teaching. The Internet TESL Journal, 8(2). http://iteslj.org/Articles/Belchamber-CLT.html (accessed 20/07/2021).

[4] Brown, H. D. (2000). Principles of language learning and teaching (4th ed). Englewood Cliffs, NJ: Prentice Hall.

[5] Canale, M. (1983). From communicative competence to communicative language pedagogy. In Richards, J. C., \& Schmidt, R. W. (Eds.), Language and Communication, 2-27. London: Longman.

[6] Chomsky, N. (1965). Aspects of the Theory of Syntax. Cambridge, Massachusetts: The M.I.T. Press.

[7] Dornyei, Z. (2010). Research methods in applied linguistics. Oxford: Oxford University Press.

[8] Farooqui, S. (2014). The struggle to teach in English: A case study in Bangladesh. Journal of Education and Human Development, 3(2): 441-457. DOI: 10.15640/jehd

[9] Gautam, K. K. (1998). English language teaching: A critical study of methods and approaches. New Delhi: Harman Publishing House.

[10] Hamid, O. M. (2010). Globalization, English for everyone and English teacher capacity: Language policy discourses and realities in Bangladesh. Current Issues in Language Planning, 11(4): 289-310. https://doi.org/10.1080/14664208.2011.532621

[11] Hymes, D. 1972). On communicative competence. In J.B. Pride and J. Holmes (edi.), Sociolinguistics. Harmondsworth: Penguin, 269-93.

[12] Khan, R. (2000). The English foundation course at Dhaka University: An evaluation. The Dhaka University Studies, 77-110.

[13] Larsen-Free-man, D. (2004). Techniques and principles in language teaching ( $2^{\text {nd }}$ edi). Oxford: Oxford University Press.

[14] Littlewood, W. (1981). Communicative language teaching: An Introduction. Cambridge: Cambridge University Press.

[15] Mamun, A. A. (2015). Designing a needs-based English syllabus for university. PhD Dissertation. Rajshahi: Rajshahi University, Bangladesh.

[16] Marks, J. (2008). Methodology of the grammar translation method. One Stop English. <http://www.onestopenglish. com/section. asp? docid $=146406>($ accessed 20/07/2021).

[17] Nagraj, G. (1996). English language teaching approaches, methods, \& techniques. New Delhi: Orient Longman Ltd.

[18] O'Neill, R. (2000). The appeal and poverty of communicative language teaching. The IH Journal of Education and Development, 8:3-9. https://www.scribd.com/document/330152637/IH- Journal-Issue-8 (accessed 20/07/2021).

[19] Rabbini, R. (2002). An introduction to syllabus design and evaluation. The Internet TESOL Journal 8(5). http://iteslj.org/Articles/Rabbini-Syllabus.html (accessed 20/07/2021).

[20] Rahman et.al. (2019). English language teaching in Bangladesh today: Outcomes and implications. Language Testing in Asi 9(9):1-14.http://doi.org/10.1186/s40468-019-0085-8 .

[21] Rahman, H. M. \& Jelane, M.M. (2021). Engineering students' EFL needs at the tertiary level of education in Bangladesh: Expectations and existence. International Journal of Language and Literary Studies. 3(2): 114-125. https://doi.org/10.36892/ijlls.v3i2.542

[22] Richards, J. C., Theodore S. R. (2001) Approaches and methods in language teaching. Cambridge: Cambridge University Press.

[23] Richards, J. C. (2006). Communicative language teaching today. New York: Cambridge University Press.

[24] Sudha, M.M. (2017). The effectiveness of English language courses as EFL in undergraduate level at Jahangirnagar University. International Journal of English Language Teaching. 5(8):7-26. www.eajournals.org.

[25] Sultana S. (2021). Indigenous ethnic languages in Bangladesh: Paradoxes of the multilingual ecology. Ethnicities. doi:10.1177/14687968211021520

[26] Sultana, F., Sultana, N., \& Zakaria, AKM. (2019). An evaluation of fundamental English courses: A scrutiny of their effectiveness at an engineering university, Bangladesh. International Journal of English and Literature (IJEL), 9 (3): 47-62. DOI:10.24247/ijeljun20195 
[27] Stern, H.H. (1984). Review and discussion. In C.J. Brumfit (Eds.). General English syllabus design. Oxford: Pergamon Press, 5-11.

[28] Stern, H.H. (1984). Syllabus design in general education: Option for ELT. In C.J. Brumfit (eds.). General English syllabus design. Oxford: Pergamon Press, 23-28.

[29] The constitution of the people's republic of Bangladesh. (2021). Article no.3. http://bdlaws.minlaw.gov.bd/ (accessed 20/07/2021)

[30] Thullen, N. (1996). The grammar translation method. http://www.nthuleen.com/papers/720report.html (accessed 20/07/2021).

[31] University Grant Commission (UGC) of Bangladesh. (2021). http://www.bangladesh.gov.bd/ (accessed 20/07/2021).

[32] Wali, O. (2018). Future undergraduate English language curriculum framework for sustainable development in Bangladesh. International Journal of English Learning and Teaching Skills, 1(2): 170-179. DOI: doi.org/10.15864/ijelts. 1209

[33] Widdoson, H.G. (1978). Teaching language as communication. Oxford: Oxford University Press.

[34] Wilkins, D. (1976). Notional syllabuses. Oxford: Oxford University Press.

[35] Willis, D. (1990). The lexical syllabus. Collins ELT: London and Glasgow. https://www.birmingham.ac.uk/Documents/collegeartslaw/cels/lexicalsyllabus/lexsch1.pdf (accessed 20/07/2021).

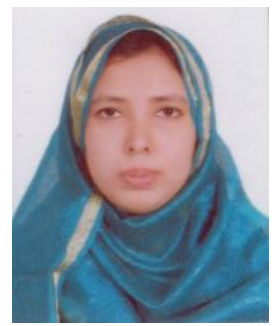

Amina Rashid earned her Bachelor of Arts in English from Khulna University, Khulna, Bangladesh, in 2007; and Master of Arts in English from Khulna University, Khulna, Bangladesh in 2010. Her graduate degrees focused on language and literature.

Amina is currently a lecturer in the Institute of English Language at Jazan University, Saudi Arabia. Alongside her several publications; she has presented papers in different conferences. She teaches both English for General Purpose (EGP) and English for Specific Purpose (ESP). Her research interest includes teaching methods, syllabus and curriculum design, language acquisition.

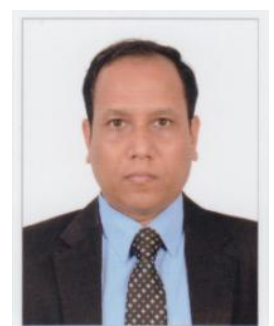

Md. Masud Rana received his Bachelor of Arts in English from Islamic University, Kushita, Bangladesh, in 2003; and Master of Arts in English from Islamic University, Kushtia, Bangladesh in 2007; Master of Arts in Applied Linguistics and ELT from State University of Bangladesh, Dhaka, Bangladesh in 2009. His graduate degrees focused on literature, applied linguistics and ELT.

$\mathrm{He}$ is currently a lecturer in the Institute of English Language at Jazan University, Saudi Arabia. Previously, he taught English language and literature in the department of English, Asian University of Bangladesh, Uttara, Dhaka, Bangladesh. Among his various publications, he has presented papers in several conferences. His research interest includes learning strategies, Motivation, teaching methods, language acquisition. 